\title{
Diffusive emissions of methane and nitrous oxide from a cascade of tropical hydropower reservoirs in Kenya
}

\author{
Eric O. Okuku ${ }^{1,2}$ (D) | Steven Bouillon ${ }^{1} \mid$ Mwakio Tole $^{3} \mid$ Alberto V. Borges ${ }^{4}$
}

${ }^{1}$ Department of Earth and Environmental Sciences, Katholieke Universiteit Leuven, Leuven, Belgium

${ }^{2}$ Kenya Marine and Fisheries Research Institute, Mombasa, Kenya

${ }^{3}$ School of Agriculture and Environmental Sciences, Department of Environmental Sciences, Pwani University, Kilifi, Kenya

${ }^{4}$ Unité d'Océanographie

Chimique, Université de Liège, Liège, Belgium

\section{Correspondence}

Eric O. Okuku, Department of Earth and Environmental Sciences, Katholieke Universiteit Leuven, Celestijnenlaan 200E, Box 2411, 3001 Leuven, Belgium.

Email: ochiengokuku2003@yahoo.com

\section{Funding information}

Flemish Interuniversity Council - University Cooperation for Development (VLIRUOS, Belgium), Grant/Award Number: ICP programme; Flemish Interuniversity Council; European Research Council

\begin{abstract}
The present study investigated diffusive emissions of methane $\left(\mathrm{CH}_{4}\right)$ and nitrous oxide $\left(\mathrm{N}_{2} \mathrm{O}\right)$ to the atmosphere from three relatively small $\left(3-120 \mathrm{~km}^{2}\right)$ reservoirs (Masinga, Kamburu and Gitaru) on the Tana River (Kenya). Sampling was conducted biweekly in 2011, 2012 and 2013, at sampling sites upstream and downstream of these reservoirs while five sampling campaigns were carried out in 2011, 2012 and 2013 for different sites within each of the reservoirs. The dissolved $\mathrm{CH}_{4}$ (range: 19-2101 nmol/L) and $\mathrm{N}_{2} \mathrm{O}$ (range: 6.2-11.5 nmol/L) concentrations in the surface waters were generally very low in the three reservoirs, compared with other reservoirs globally. The lower diffusive emissions of $\mathrm{CH}_{4}\left(20-216 \mu \mathrm{mol} / \mathrm{m}^{2}\right.$ day $\left.{ }^{-1}\right)$ and $\mathrm{N}_{2} \mathrm{O}\left(1.0-1.6 \mu \mathrm{mol} / \mathrm{m}^{2} \mathrm{day}^{-1}\right)$ from these reservoirs, compared with other tropical reservoirs, are probably related to their age (30-40 years), and lower vegetation biomass (savannah) originally present and submerged during their commissioning. The reservoirs with longer water residence times were characterized by higher diffusive $\mathrm{CH}_{4}$ fluxes $\left(216 \pm 666 \mu \mathrm{mol} / \mathrm{m}^{2} \mathrm{day}^{-1}\right)$ and slightly lower $\mathrm{N}_{2} \mathrm{O}$ fluxes $(1.0 \pm 1.5 \mu \mathrm{mol} /$ $\mathrm{m}^{2}$ day $^{-1}$ ). The relative contribution of turbine fluxes of $\mathrm{CH}_{4}$ and $\mathrm{N}_{2} \mathrm{O}$, compared to diffusive fluxes, was also highly variable among the three dams, being lower in Masinga Reservoir and higher in Gitaru Reservoir.
\end{abstract}

\section{KEYWORDS}

African (tropical) reservoirs, greenhouse gases, Methane emissions, nitrous oxide emissions

\section{1 | INTRODUCTION}

The damming of rivers has been integral to human population growth, economic development and technological innovation through the provision of a reliable water supply, security from flooding, irrigation water for agriculture and generation of electricity (Deemer et al., 2016; Snoussi et al., 2007). About 16.7 million reservoirs have been constructed, with a combined storage capacity of $\sim 8,070 \mathrm{~km}^{3}$ and resultant increase in freshwater surface area by more than $305,000 \mathrm{~km}^{2}$, and an associated retention and degradation of carbon (C) (Maavara, Lauerwald, Regnier, \& Cappellen, 2016). The increased $C$ retention and processing results in the reservoirs producing elevated levels of greenhouse gases (GHGs), including carbon dioxide
$\left(\mathrm{CO}_{2}\right)$, methane $\left(\mathrm{CH}_{4}\right)$ and nitrous oxide $\left(\mathrm{N}_{2} \mathrm{O}\right.$; Barros et al., 2011; Deemer et al., 2016; Maeck et al., 2013; St. Louis, 2000; Yang et al., 2014). $\mathrm{CH}_{4}$ and $\mathrm{N}_{2} \mathrm{O}$ are powerful GHGs with global warming potential (GWPs), being 32 and 310 times worse than $\mathrm{CO}_{2}$ over a 100-year time horizon (IPCC, 2013). GHG emissions from reservoirs result from degradation of submerged biomass, allochtonous inputs and autochtonous production (Kemenes, Forsberg, \& Melack, 2007, 2011; Teodoru et al., 2012), and are influenced by the age of a reservoir (Abril et al., 2005G; Barros et al., 2011).

Reservoirs (manmade lakes) are currently considered significant contributors of atmospheric GHGs (Barros et al., 2011; Bastviken, Tranvik, Downing, Crill, \& Enrich-Prast, 2011; St. Louis et al., 2000). Raymond et al. (2013), for example, estimated inland 
waters emit carbon dioxide $\left(\mathrm{CO}_{2}\right)$ at a rate of $2.1 \mathrm{Pg} \mathrm{C} /$ year, with emissions from hydroelectric reservoirs representing around $2 \%$ of this flux (49 Tg C/year), whereas Barros et al. (2011) estimated hydroelectric reservoirs emit about 48 and $3 \mathrm{Tg} \mathrm{C} /$ year as $\mathrm{CO}_{2}$ and methane $\left(\mathrm{CH}_{4}\right)$, respectively, corresponding to about $4 \%$ of global carbon (C) emissions from inland waters. Deemer et al. (2016) revised upward the global reservoir GHGs emissions to $13.4 \mathrm{Tg}$ $\mathrm{CH}_{4}$ and $0.03 \mathrm{Tg} \mathrm{N} \mathrm{N}_{2} \mathrm{O}$ per year. The latter $\mathrm{CH}_{4}$ fluxes were higher than the previous estimates since they consider fluxes from temperate reservoirs (Beaulieu et al., 2014; Maeck et al., 2013) and sub-tropical reservoirs (Grinham, Dunbabin, Gale, \& Udy, 2011; Sturm, Yuan, Gibbes, Werner, \& Grinham, 2014) not included in previous global estimates, but whose emissions are as significant as those from tropical systems. Nevertheless, only a handful of studies globally have analysed the contribution of nitrous oxide $\left(\mathrm{N}_{2} \mathrm{O}\right)$ to total GHG emissions from reservoirs (Deemer et al., 2016; Descloux, Chanudet, Serça, \& Guérin, 2017; Guérin, Abril, Tremblay, \& Delmas, 2008; Tremblay, Varfalvy, Roehm, \& Garneau, 2005), despite $\mathrm{N}_{2} \mathrm{O}$ having a higher global warming potential (GWP) compared with $\mathrm{CH}_{4}$. Further, there are sparse data from the tropical areas, although tropical reservoirs exhibit high run-offs and associated high organic carbon loads resulting from irregular and heavy precipitation (Tundisi, Matsumura-Tundisi, \& Calijuri, 1993), as well as nearly constant and elevated temperatures that causes thermal stratification and deoxygenation of bottom waters (Barros et al., 2011; Tundisi \& Tundisi, 2012). These conditions are known to be favourable conditions for enhanced $\mathrm{CH}_{4}$ and $\mathrm{N}_{2} \mathrm{O}$ production and emissions (Demarty \& Bastien, 2011; Fearnside, 1995; Galy-Lacaux, Delmas, Kouadio, Richard, \& Gosse, 1999; Guérin et al., 2008).

GHG emissions from reservoirs have led to controversy on the contribution of reservoirs to global warming, despite justifications by various authorities that hydroelectric power generation is a green energy (i.e. produces lower GHG emissions compared to fossil fuel) (Deemer et al., 2016; Hoffert et al., 1998; Victor, 1998). According to IPCC guidelines, tropical countries relying heavily on hydroelectricity are at a risk of having their national GHG emission inventories increased by as much as 7\% (IPCC2006). Thus, it is a requirement that these countries work towards reducing uncertainties regarding the role of reservoirs in climate change and global warming by including them in their National GHGs Inventory Programme. Hydropower is an important renewable energy in Kenya, accounting for about $50 \%$ of installed capacity, with more reservoirs yet to be commissioned. Thus, there is a need to better understand the role of reservoirs in GHG emissions in Kenya. To this end, the present study investigated the role of cascading reservoirs in the production and emission of $\mathrm{CH}_{4}$ and $\mathrm{N}_{2} \mathrm{O}$ from three large reservoirs (Masinga; Kamburu; Gitaru) in the Tana River network in Kenya.

\section{2 | MATERIALS AND METHODS}

\section{1 | Study sites}

The present study was carried out in the Tana River basin, Kenya (Figure 1). The Tana River has a length of $\sim 1,000 \mathrm{~km}$, originating in the Aberdare ranges and Mount Kenya of central Kenya and running through the arid and semi-arid lands in the eastern part of the country to enter the Indian Ocean through a fan-shaped delta. The Tana River basin experiences a bimodal precipitation pattern, with dominant rainy seasons occurring during April-June and OctoberDecember. The basin experiences variable rainfall patterns, decreasing from the headwaters $(\sim 1,800 \mathrm{~mm}$ /year), upper highlands ( 2,200 mm/year), mid-altitude catchment ( $900-2,000 \mathrm{~mm} /$ year) to the lower semi-arid Tana catchment (450-900 mm/year; Brown \& Schneider, 1998).

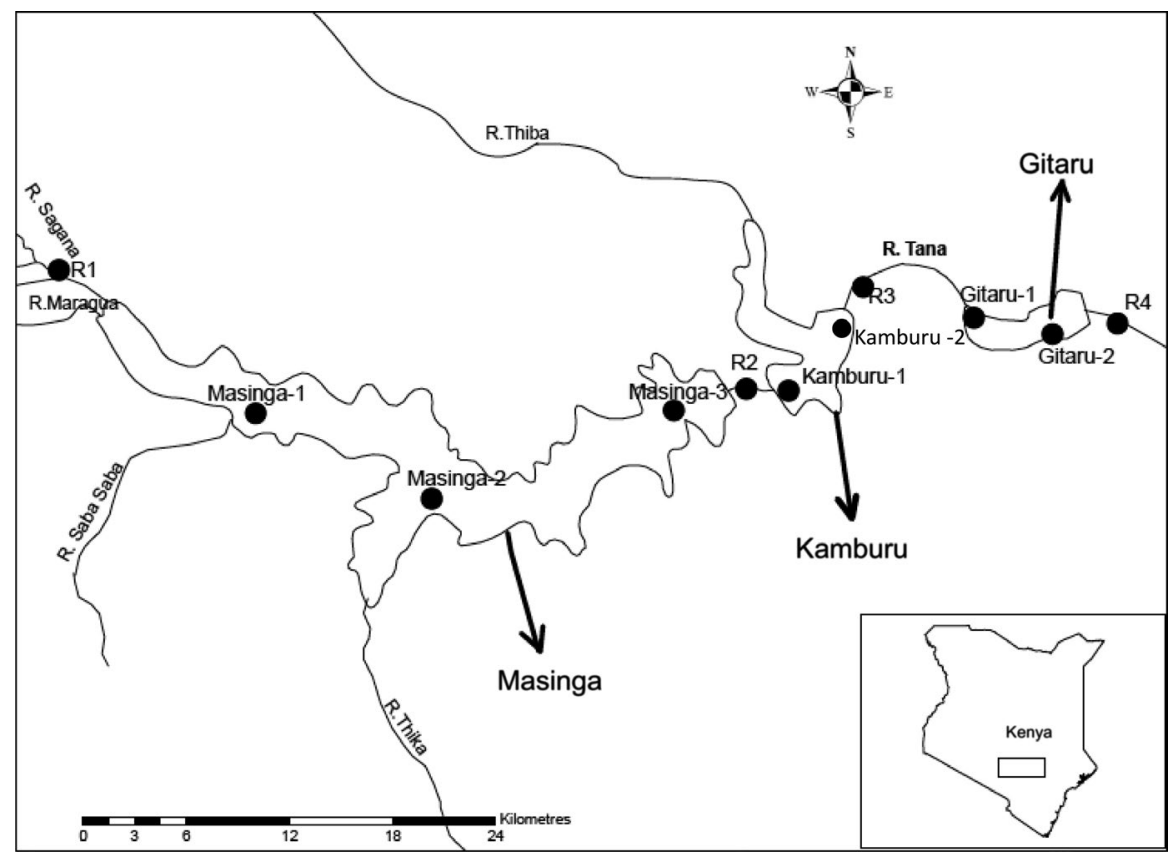

FIGURE 1 Sampling sites in the three cascading reservoirs of Tana River, Kenya 
Five cascading reservoirs were constructed along the Tana River between 1968 and 1981. The Masinga, Kamburu and Gitaru reservoirs were selected for the present study because of their different sizes, depth profiles and residence times (Table 1).

The samples river sections were upstream of Masinga Reservoir (R1), between the three dams (below Masinga Reservoir (R2) and below Kamburu Reservoir (R3)), and below Gitaru Reservoir (R4). Three sampling sites also were selected within Masinga Reservoir (along the water flow path: Masinga-1, -2 and -3) because of its larger size, while two sites were selected within Kamburu Reservoir (Kamburu-1 and -2) and Gitaru Reservoir (Gitaru-1 and -2; Figure 1). The sampling sites on the upper reaches of the reservoir were located near the reservoir inlet (characterized by high water flow rates), while the lower reach sites were located towards the reservoir outlets (close to the turbines and characterized by lower water flow rates), whereas the mid-reach sites were located roughly halfway across the reservoir length. Other small rivers flowing into the reservoirs (e.g., Sabasaba, Thika, Chania and Thiba rivers) were not sampled in the present study because of logistical constraints.

\section{2 | Field measurements and sample collection}

Samples were collected biweekly at the inflows and outflows from the three study reservoirs during five sampling campaigns (20112013) at sites within the reservoirs (Figure 2). No spillover discharges from the reservoirs occurred during the five campaigns. Water samples from the reservoirs were collected using a vertical Niskin bottle (4 L), whereas the sampling sites upstream and downstream of reservoirs and the sites between the reservoirs were sampled with a plastic bucket $(10 \mathrm{~L})$.

Temperature, electric conductivity, $\mathrm{pH}$ and dissolved oxygen (DO) concentrations were measured in situ using a hand-held multiparameter metre (YSI Pro Plus). Water samples for determining dissolved ammonium $\left(\mathrm{NH}_{4}{ }^{+}-\mathrm{N}\right)$ and nitrate + nitrite $\left\{\left(\mathrm{NO}_{3}{ }^{-}+\mathrm{NO}_{2}{ }^{-}\right)-\mathrm{N}\right\}$ concentrations were collected in acid pre-washed polyethylene bottles following double filtration on pre-combusted $47 \mathrm{~mm}$ GF/F filters and through $0.2-\mu \mathrm{m}$ syringe filters. Nutrient samples $(50 \mathrm{ml}$ ) were preserved by adding $50 \mu \mathrm{l}$ of a saturated mercuric chloride $\left(\mathrm{HgCl}_{2}\right)$ solution. Methane $\left(\mathrm{CH}_{4}\right)$ and nitrous oxide $\left(\mathrm{N}_{2} \mathrm{O}\right)$ samples were collected with $50-\mathrm{mL}$ serum bottles, poisoned with $100 \mu \mathrm{l}$ of a saturated solution of $\mathrm{HgCl}_{2}$ and capped with a butyl-rubber stopper and aluminium cap. To avoid gas exchange with the atmosphere, the $\mathrm{CH}_{4}$ and $\mathrm{N}_{2} \mathrm{O}$ samples were collected with a rubber tube from the bottom of the Niskin bottles. In those cases where that Niskin bottles could not be used (e.g., sampling sites between the study reservoirs), water samples were drawn from a $0.5 \mathrm{~m}$ depth below the river surface directly into sampling bottles.

\section{3 | Sample preparation and analysis}

$\mathrm{CH}_{4}$ and $\mathrm{N}_{2} \mathrm{O}$ concentrations were determined via a headspace equilibration technique $(20 \mathrm{ml} \mathrm{N}$ headspace in $50-\mathrm{ml}$ serum bottles) and measured with a gas chromatograph (SRI 8610C) with flame ionization detection, and electron capture detection calibrated with $\mathrm{CH}_{4}: \mathrm{CO}_{2}: \mathrm{N}_{2} \mathrm{O}: \mathrm{N}_{2}$ mixtures (Air Liquide Belgium) of 1,10 and 30 ppm $\mathrm{CH}_{4}$ and of 0.2, 2.0 and 6.0 ppm $\mathrm{N}_{2} \mathrm{O}$ (Borges et al., 2015). The methods described by Parsons, Maita, and Lally (1984) and APHA (1998) were used to analyse the dissolved ammonium $\left(\mathrm{NH}_{4}{ }^{+} \mathrm{N}\right)$, nitrate $+\mathrm{ni}-$ trite $\left\{\left(\mathrm{NO}_{3}{ }^{-}+\mathrm{NO}_{2}{ }^{-}\right)-\mathrm{N}\right.$ concentrations in the water samples. Dissolved $\mathrm{NH}_{4}{ }^{+}-\mathrm{N}$ concentrations were determined using the indophenol method and measured at $630 \mathrm{~nm}$ after at least 6 hr' incubation. Dissolved $\left(\mathrm{NO}_{3}{ }^{-}+\mathrm{NO}_{2}{ }^{-}\right)-\mathrm{N}$ concentrations were determined using the cadmium reduction method, measured colorimetrically at $543 \mathrm{~nm}$.

Diffusive fluxes of $\mathrm{CH}_{4}$ and $\mathrm{N}_{2} \mathrm{O}$ at the air-water interface were calculated using gas exchange velocities calculated from the empirical relationships with wind speed as proposed by Cole and Caraco (1998), using wind speed obtained from the National Centers for Environmental Prediction (NCEP) gridded daily product (grid point: $\left.-0.95237^{\circ} \mathrm{N}, 37.50000^{\circ} \mathrm{E}\right)$. The emissions were further converted to $\mathrm{CO}_{2}$ equivalents ( 1 mass unit of trace GHG to the emission caused by 1 mass unit of $\mathrm{CO}_{2}$ over a 100 years) to obtain the relative contribution of the various GHG emissions to global warming (Deemer et al., 2016).

The turbine flux was calculated as the product of the turbine discharge and the difference between the observed $\mathrm{CH}_{4}$ (or $\mathrm{N}_{2} \mathrm{O}$ ) concentration at the water withdrawal depth and the concentrations at equilibrium with the atmosphere. This flux estimate corresponds to the maximum potential emission since it assumes full degassing and equilibration with the atmosphere during the transit through the turbines. The computations were made for March 2011, July 2011, January 2012, May 2012 and February 2013, when vertical profiles were obtained for the reservoir intakes.

\section{3 | RESULTS AND DISCUSSION}

There were seasonal variations and different patterns in regard to the biogeochemical variables sampled in the river and study reservoirs (Table 2). The surface water temperature was higher

TA B LE 1 Main characteristics of Masinga, Kamburu and Gitaru reservoirs on the Tana River (modified from Brown, Schneider, \& Harper, 1996; water residence time calculated using discharge data for 2011 and 2012)

\begin{tabular}{llllllll} 
Reservoir & Altitude $(\mathrm{m})$ & Year commissioned & $\begin{array}{l}\text { Capacity } \\
\left(\times 10^{6} \mathrm{~m}^{3}\right)\end{array}$ & $\begin{array}{l}\text { Surface } \\
\text { area }\left(\mathrm{km}^{2}\right)\end{array}$ & $\begin{array}{l}\text { Maximum depth at } \\
\text { commissioning }(\mathrm{m})\end{array}$ & $\begin{array}{l}\text { Installed ca- } \\
\text { pacity (MW) }\end{array}$ & $\begin{array}{l}\text { Residence } \\
\text { time }(\mathrm{days})\end{array}$ \\
\hline Masinga & 1,050 & 1981 & 1560 & 120 & 50 & 40 & 149 \\
Kamburu & 1,010 & 1974 & 123 & 15 & 56 & 30 & 16 \\
Gitaru & 924 & 1978 & 20 & 3.1 & 30 & 225 & 3 \\
\hline
\end{tabular}




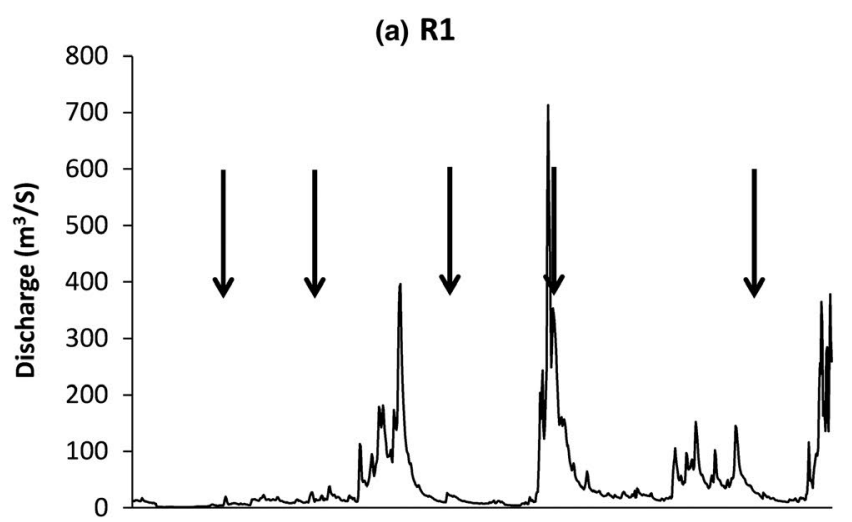

(c) R3

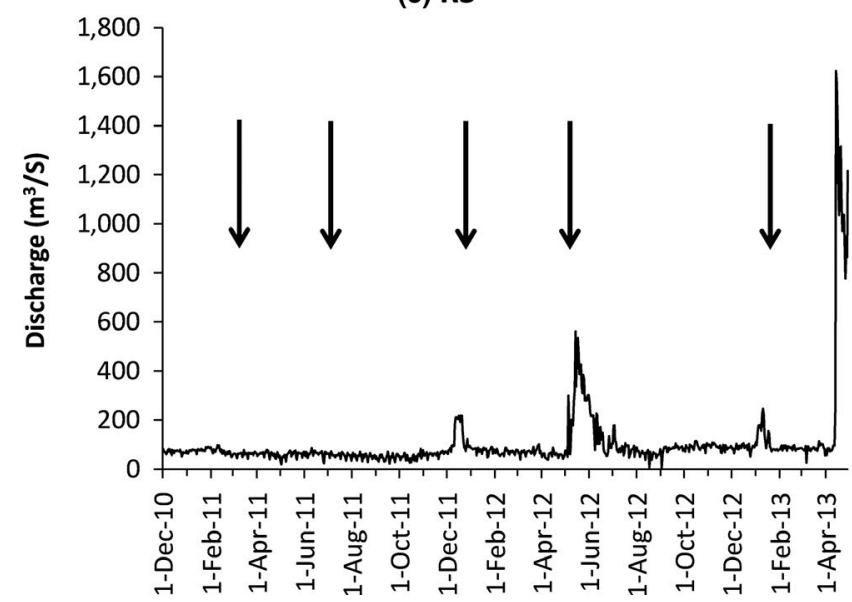

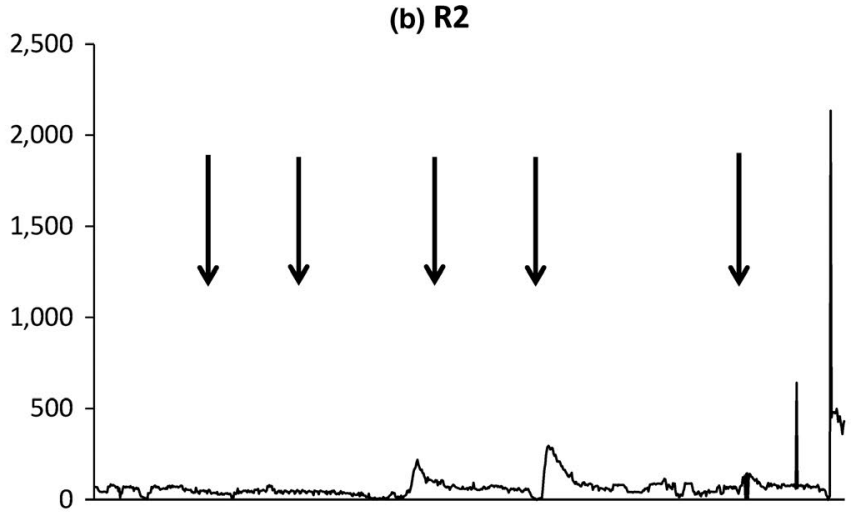

(d) R4

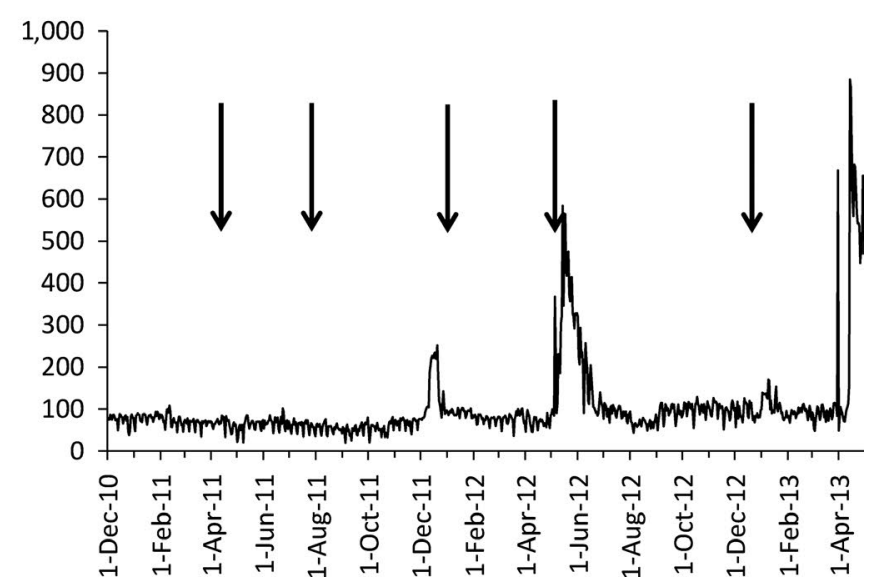

FIGURE 2 Time series of discharges at different sampling sites (arrows showing sampling dates: 17/3/2011-21/3/2011; 15/7/201118/7/2011; 19/1/2012-22/12/2012; 20/5/2012-22/5/2012 and 8/2/2013-10/2/2013)

$(F=14.02 ; p<0.01)$ in the reservoirs (range: $\left.21.1-28.0^{\circ} \mathrm{C}\right)$, compared with the most upstream river station (R1; range: $\left.20.6-25.7^{\circ} \mathrm{C}\right)$. The DO concentrations were similar $(F=0.091 ; p>0.05)$ for both the reservoir surface (5.27-9.35 $\mathrm{mg} / \mathrm{L}$ ) and R1 (4.4-10.0 mg/L) sampling sites. The $\mathrm{CH}_{4}$ concentrations in the surface water of the reservoirs were generally low (compared with other tropical reservoirs), averaging 63, 55 and $28 \mathrm{nmol} / \mathrm{L}$ in Masinga, Kamburu and Gitaru reservoirs, respectively, indicating a decreasing pattern along the cascade of reservoirs, as well as along the size gradient, with the largest reservoirs having the longest water residence times, and

TAB LE 2 Mean environmental variables at sampling sites (average \pm standard deviation) in upstream and downstream rivers (R1, R2, R3 and R4) and within Masinga (Masinga-1, Masinga-2 and Masinga-3), Kamburu (Kamburu-1 and Kamburu-2) and Gitaru (Gitaru-1 and Gitaru-2) reservoirs

\begin{tabular}{|c|c|c|c|c|c|c|}
\hline Sampling site & Temperature $\left({ }^{\circ} \mathrm{C}\right)$ & $\begin{array}{l}\text { Dissolved oxygen } \\
\text { (DO) (mg/L) }\end{array}$ & $\begin{array}{l}\text { Electrical conduc- } \\
\text { tivity }(\mu \mathrm{S} / \mathrm{cm})\end{array}$ & $\mathrm{pH}$ & $\begin{array}{l}\text { Ammonia }\left(\mathrm{NH}_{4}^{+}\right) \\
(\mu \mathrm{mol} / \mathrm{L})\end{array}$ & $\begin{array}{l}\text { Nitrate } \\
\left(\mathrm{NO}_{3}\right)^{-}(\mu \mathrm{mol} / \mathrm{L})\end{array}$ \\
\hline R1 & $22.2 \pm 1.0$ & $7.49 \pm 1.00$ & $111 \pm 13$ & $7.30 \pm 0.09$ & $1.31 \pm 0.57$ & $3.90 \pm 1.94$ \\
\hline Masinga-2 & $26.4 \pm 0.4$ & $6.82 \pm 0.43$ & $136 \pm 10$ & $8.19 \pm 0.08$ & $1.04 \pm 0.48$ & $3.64 \pm 2.04$ \\
\hline Masinga-3 & $25.2 \pm 0.5$ & $7.05 \pm 0.63$ & $129 \pm 11$ & $7.96 \pm 0.07$ & $0.80 \pm 0.28$ & $4.78 \pm 2.55$ \\
\hline Kamburu-1 & $25.3 \pm 1.0$ & $7.48 \pm 0.74$ & $122 \pm 8$ & $8.15 \pm 0.14$ & $0.92 \pm 0.39$ & $3.81 \pm 2.03$ \\
\hline Kamburu-2 & $25.5 \pm 0.6$ & $6.96 \pm 0.48$ & $129 \pm 10$ & $8.03 \pm 0.14$ & $1.27 \pm 0.45$ & $3.99 \pm 1.55$ \\
\hline R3 & $24.0 \pm 0.4$ & $6.48 \pm 0.40$ & $124 \pm 16$ & $7.25 \pm 0.36$ & $1.31 \pm 0.57$ & $4.02 \pm 2.13$ \\
\hline Gitaru-1 & $23.8 \pm 0.6$ & $6.91 \pm 0.24$ & $126 \pm 13$ & $7.43 \pm 0.16$ & $0.97 \pm 0.14$ & $5.23 \pm 2.38$ \\
\hline Gitaru-2 & $25.5 \pm 0.6$ & $7.44 \pm 0.42$ & $126 \pm 9$ & $7.79 \pm 0.19$ & $1.36 \pm 0.37$ & $5.33 \pm 1.99$ \\
\hline
\end{tabular}


FIGURE 3 Seasonal evolution of methane $\left(\mathrm{CH}_{4}\right)$ and nitrous oxide $\left(\mathrm{N}_{2} \mathrm{O}\right)$ concentrations in surface waters of Masinga, Kamburu and Gitaru reservoirs from December 2010 to July 2013 (inlet sites include Masinga-1, Kamburu-1 and Gitaru-1; intake sites include Masinga-3, Kamburu-2 and Gitaru 2)
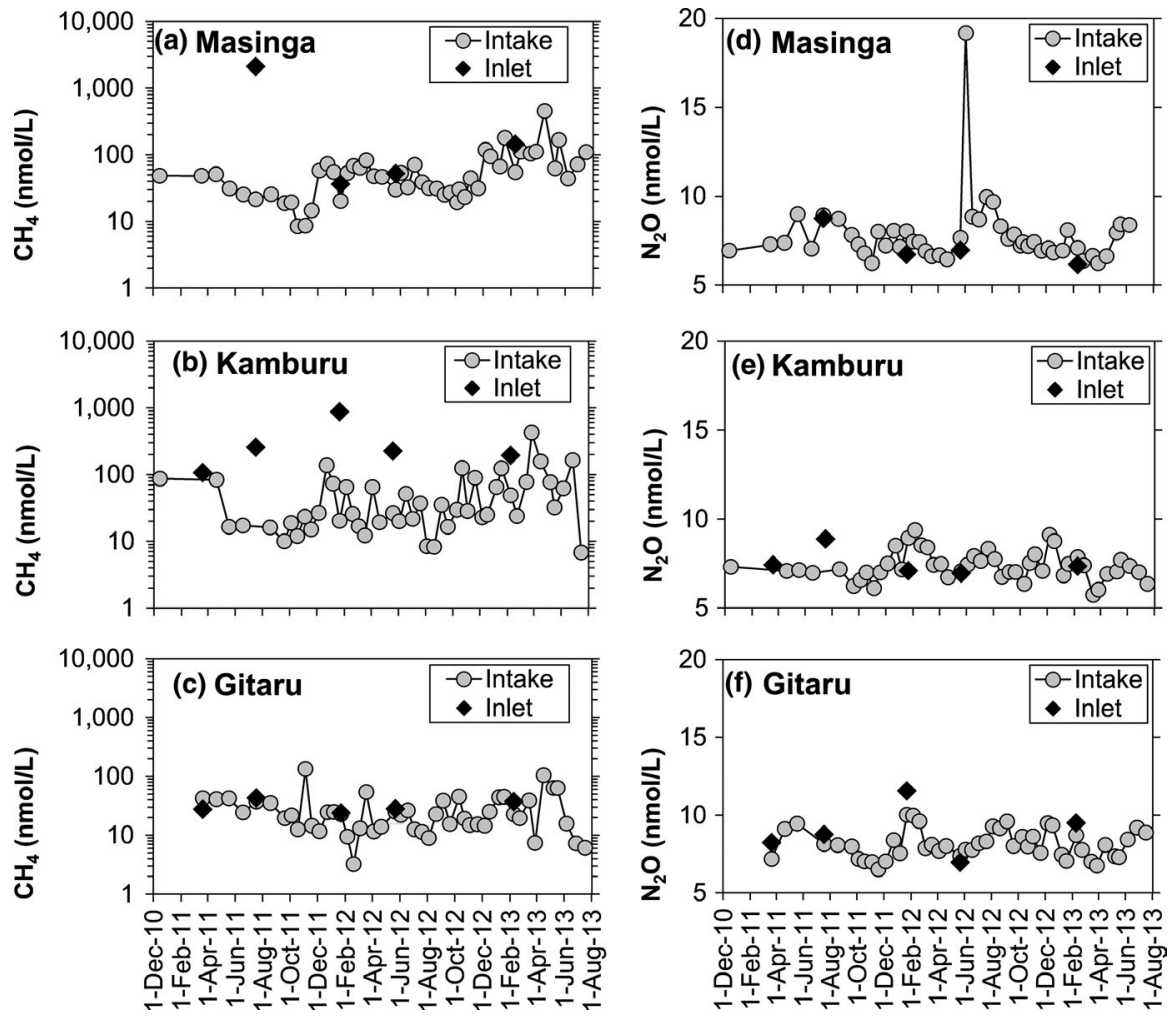

slightly higher surface water concentrations. The overall amplitude of the $\mathrm{CH}_{4}$ concentration temporal variations was also relatively modest, with minimum-maximum ranges of $8-454 \mathrm{nmol} / \mathrm{L}$ in Masinga, 7-425 nmol/L in Kamburu and 3-134 nmol/L in Gitaru. The overall amplitude of the $\mathrm{CH}_{4}$ concentration temporal variations also followed the pattern of size as average concentration. Masinga and Gitaru reservoirs only exhibited small differences between the values at the inlet (upper reach sites) sites and the intake sites (lower reach sites), whereas a marked difference was observed for Kamburu Reservoir, with higher $\mathrm{CH}_{4}$ concentrations in the upper reaches than in the lower reaches, possibly attributable to Thiba River inputs. Though not statistically significant, there were differences between the average $\mathrm{CH}_{4}$ concentration in the river entering the reservoir and the reservoir itself, with systematically higher $\mathrm{CH}_{4}$ average concentration values in the rivers, as well a higher temporal variability. The Sagana River (R1) exhibited an average $\mathrm{CH}_{4}$ concentration of $272 \mathrm{nmol} / \mathrm{L}$ (range: 13-1,905 nmol/L), compared with $63 \mathrm{nmol} / \mathrm{L}$ in Masinga Reservoir. The river at the outlet of Masinga Reservoir exhibited an average $\mathrm{CH}_{4}$ concentration of $839 \mathrm{nmol} / \mathrm{L}$ (range: 15-14,202 nmol/L), compared with $55 \mathrm{nmol} / \mathrm{L}$ in Kamburu Reservoir, while the Kamburu Reservoir outlet river exhibited an average $\mathrm{CH}_{4}$ concentration of $38 \mathrm{nmol} / \mathrm{L}$ (range: $5-322 \mathrm{nmol} / \mathrm{L}$ ) versus $33 \mathrm{nmol} / \mathrm{L}$ in Gitaru Reservoir.

The $\mathrm{N}_{2} \mathrm{O}$ concentrations were significantly higher $(F=7.581$; $p<0.01)$ and variable in the river upstream of the reservoirs (range: 6.9-23.0 nmol/L), compared with the sampling sites within the reservoirs (range: $6.2-11.9 \mathrm{nmol} / \mathrm{L}$ ) and the rivers downstream of the reservoirs (Figures 3, 4 and 5). The concentrations remained relatively similar, however, within the three reservoir
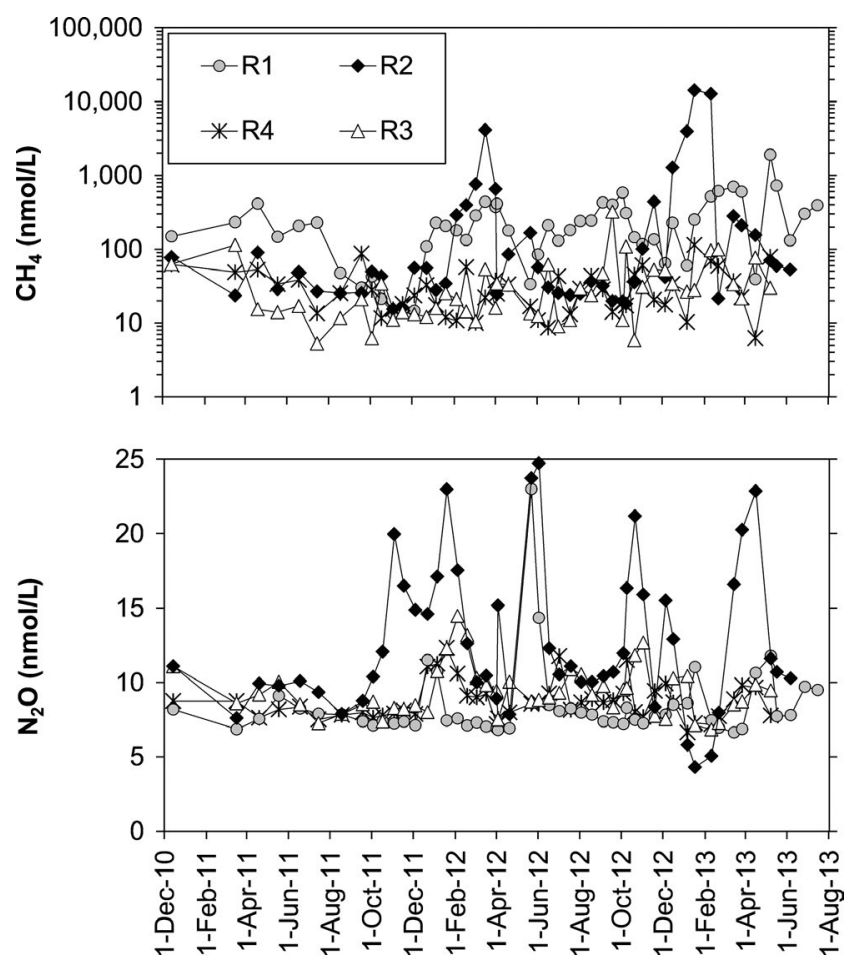

FIGURE 4 Seasonal evolution of methane $\left(\mathrm{CH}_{4}\right)$ and nitrous oxide $\left(\mathrm{N}_{2} \mathrm{O}\right)$ concentrations in surface waters of Sagana River (R1), and downstream rivers of Masinga (R2), Kamburu (R3) and Gitaru (R4) reservoirs from December 2010 to July 2013

sites, being 6.2-10.7 nmol/L; 6.9-8.9 nmol/L and 6.9-11.9 nmoI/L for Masinga, Kamburu and Gitaru reservoirs, respectively (Figure 3). 


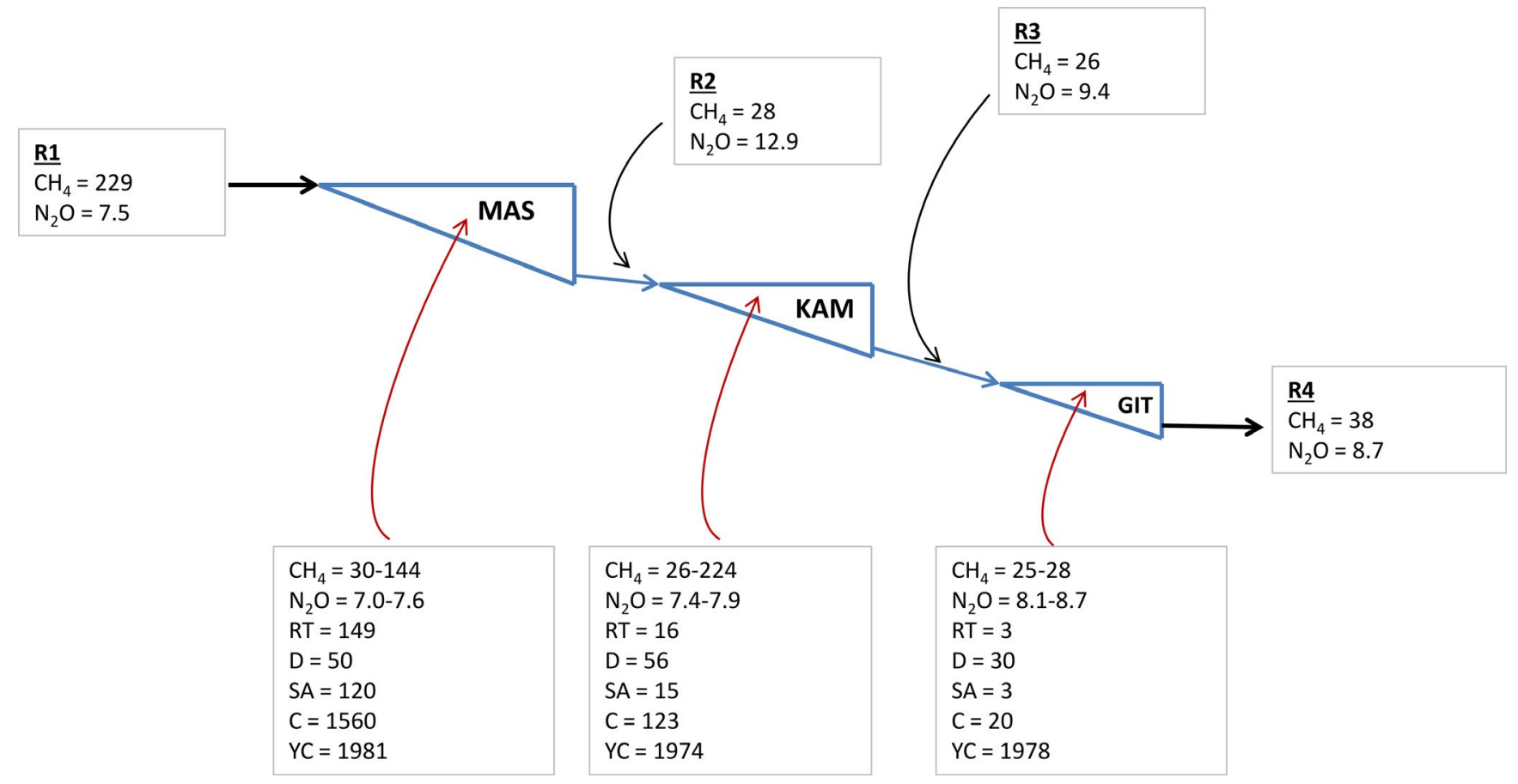

FIGURE 5 Schematic diagram summarizing medians or range of medians of methane $\left(\mathrm{CH}_{4} ; \mathrm{nM}\right)$, nitrous oxide $\left(\mathrm{N}_{2} \mathrm{O}\right.$;nM) and RT (water retention time, days), depth (D, $\mathrm{m})$, surface area $\left(\mathrm{SA} ; \mathrm{km}^{2}\right)$ and capacity $\left(\times 10^{6} \mathrm{~m}^{3}\right)$ in Masinga (MAS), Kamrubu (KAM) and Gitaru (GIT) reservoirs and riverine sites (R1, R2, R3 and R4).
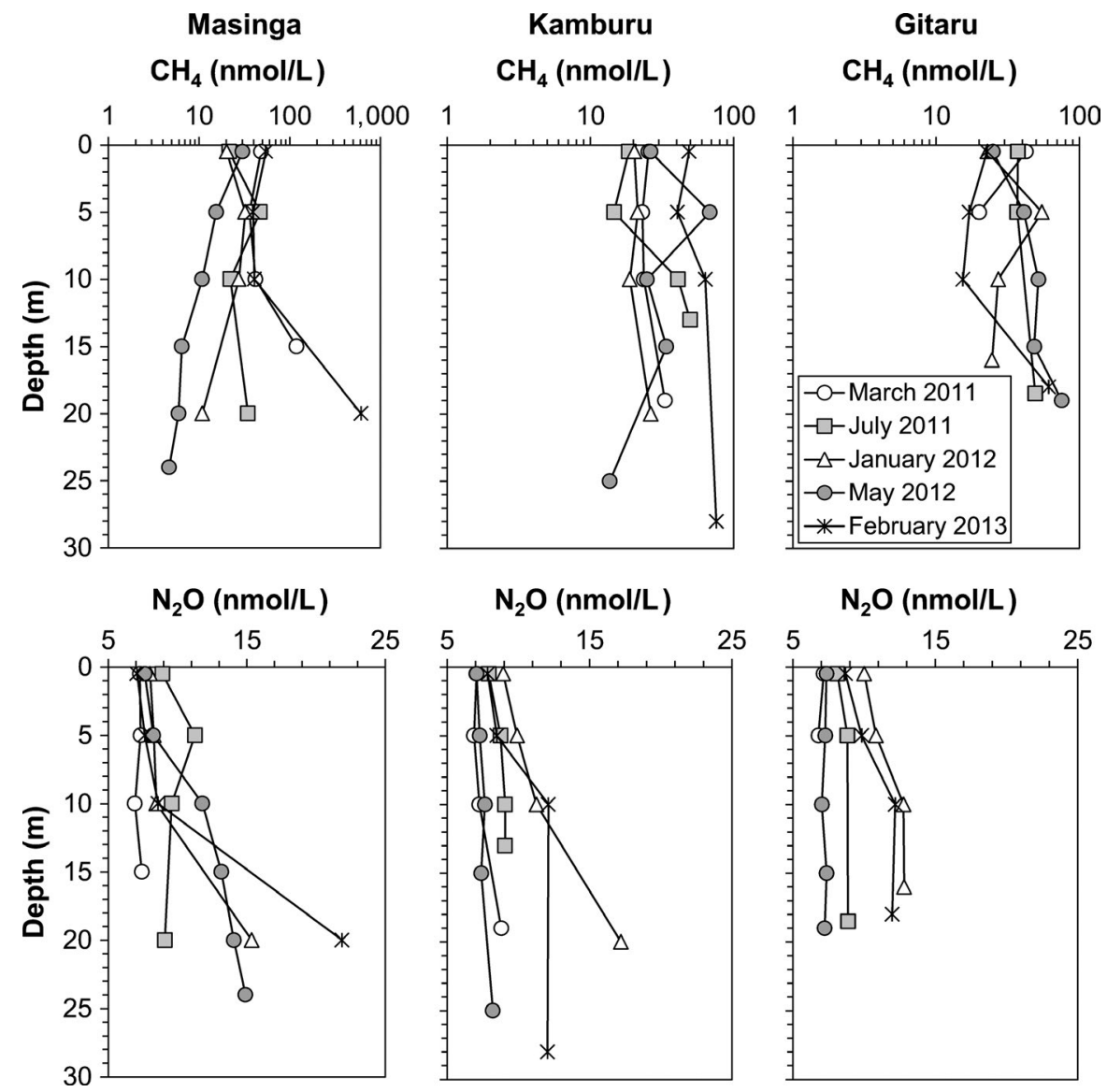

FIGURE 6 Depth profiles of methane $\left(\mathrm{CH}_{4}\right)$ and nitrous oxide $\left(\mathrm{N}_{2} \mathrm{O}\right)$ in reservoir lower reach sites (Masinga-3, Kamburu-2 and Gitaru-2) from December 2010 to July 2013 
The $\mathrm{CH}_{4}$ concentrations were generally higher in the rivers downstream of the reservoirs, whereas the $\mathrm{N}_{2} \mathrm{O}$ was generally higher at the withdrawal depth than in the river downstream of the dams (Figure 6). For logistic reasons, the rivers downstream of the reservoirs were sampled several kilometres downstream, rather than immediately below the dams, which might have resulted in instream $\mathrm{CH}_{4}$ production, and degassing of $\mathrm{N}_{2} \mathrm{O}$ to the atmosphere.

The diffusive $\mathrm{CH}_{4}$ flux in the three Tana reservoirs ranged between 20 and $216 \mu \mathrm{mol} / \mathrm{m}^{2}$ day $^{-1}$ (Table 3) with Masinga Reservoir (the largest reservoir with the longest water residence time) characterized by the highest $\mathrm{CH}_{4}$ concentration and diffusive $\mathrm{CH}_{4}$ fluxes. However, these fluxes fall within the lower end of the range of $\mathrm{CH}_{4}$ flux intensities reported so far for tropical and sub-tropical reservoirs $\left(15-100,313 \mu \mathrm{mol} / \mathrm{m}^{2} \mathrm{day}^{-1}\right)$, and well below the average of $\sim 9,000 \mu \mathrm{mol} / \mathrm{m}^{2} \mathrm{day}^{-1}$, as reported by Yang et al. (2014).

The diffusive $\mathrm{N}_{2} \mathrm{O}$ flux in the three Tana reservoirs ranged between 1.0 and $1.6 \mu \mathrm{mol} / \mathrm{m}^{2} \mathrm{day}^{-1}$ (Table 3), corresponding to the lowest $\mathrm{N}_{2} \mathrm{O}$ flux intensities reported so far for tropical and sub-tropical reservoirs. Guérin et al. (2008) reported $\mathrm{N}_{2} \mathrm{O}$ diffusive fluxes ranging between 3 and $103 \mu \mathrm{mol} / \mathrm{m}^{2} \mathrm{~d}^{-1}$ for six South American tropical reservoirs, averaging $65 \mu \mathrm{mol} / \mathrm{m}^{2} \mathrm{day}^{-1}$. Diffusive $\mathrm{N}_{2} \mathrm{O}$ fluxes were reported by Liu et al. (2011) and Zhu et al. (2013) for three sub-tropical Chinese reservoirs (Wujiangdu, $15 \mu \mathrm{mol} / \mathrm{m}^{2} \mathrm{day}^{-1}$; Hongjiadu, $10 \mu \mathrm{mol} / \mathrm{m}^{2} \mathrm{day}^{-1}$; Three Gorges Reservoir, $8 \mu \mathrm{mol} / \mathrm{m}^{2} \mathrm{day}^{-1}$ ), by Deshmukh (2013) for the sub-tropical Nam Theun 2 Reservoir $\left(\sim 15 \mu \mathrm{mol} / \mathrm{m}^{2} \mathrm{day}^{-1}\right)$ and by Deemer et al., 2016 for the global mean estimate of reservoir $\mathrm{N}_{2} \mathrm{O}$ fluxes $\left(500 \mu \mathrm{mol} / \mathrm{m}^{2}\right.$ day $\left.^{-1}\right)$.

The lower $\mathrm{CH}_{4}$ and $\mathrm{N}_{2} \mathrm{O}$ diffusive fluxes from the three Tana dams can be attributed to at least three reasons. First, the vegetation surrounding the reservoirs that was submerged during damming was open deciduous forest and grassland. Thus, the submerged biomass was less than that of tropical evergreen forests typical of South American reservoirs, for which higher $\mathrm{CH}_{4}$ and $\mathrm{N}_{2} \mathrm{O}$ were reported (Guerin \& Abril, 2007; Guérin et al., 2008). Second, the three Tana dams are characterized by $\mathrm{O}_{2}$ concentrations that decrease with depth, although strictly anoxic conditions were not encountered. This contrasts with the strongly meromictic reservoirs that exhibit anoxic bottom waters, which is typical with South American reservoirs (Guerin, \& Abril, 2007; Guérin et al., 2008). Third, the measurements reported in the present study were carried out 30-40 years after the construction of the dams, typically when the $\mathrm{CH}_{4}$ fluxes are low due to large degradation of the original submerged biomass (Abril et al., 2005G; Barros et al., 2011).

The total diffusive $\mathrm{CH}_{4}$ flux (integrated over their respective surface areas) was $28,052 \mathrm{~mol} /$ day, with a contribution roughly equivalent to a relative surface area of $92 \%$ from Masinga Reservoir, $7 \%$ for Kamburu Reservoir and $<1 \%$ for Gitaru Reservoir (Table 3). The $\mathrm{CH}_{4}$ emission by turbines was of the same order of magnitude among the three dams (range: $234-840 \mathrm{~mol} / \mathrm{day}$ ), although its relative importance with regard to the integrated diffusive emission was highly variable, being higher in the smaller reservoirs. The diffusive $\mathrm{CH}_{4}$ emission in Masinga Reservoir was 32 times higher than the turbine flux while, in contrast, the turbine flux was six times higher than the diffusive flux in Gitaru Reservoir. Up to $70 \%$ of the total reservoir $\mathrm{CH}_{4}$ emissions were attributed to turbine degassing (Abril et al., 2005G; Fearnside, 2002; Kemenes, Forsberg, \& Melack, 2007). The contribution of turbine $\mathrm{CH}_{4}$ degassing in the release of $\mathrm{CH}_{4}$ from the three studied Kenyan reservoirs was lower, given the bottom waters in the reservoirs were not anoxic. The reported flux ranges, however, were much lower, compared with those reported for Lake Kariba, the only other African reservoir intensively studied for $\mathrm{CH}_{4}$ fluxes. Diffusive fluxes in Lake Kariba ranged between 5 and 5,000 $\mu \mathrm{mol} / \mathrm{m}^{2}$ day $^{-1}$, with a dominance of fluxes from ebullition ranging between 5 and $50,000 \mu \mathrm{mol} / \mathrm{m}^{2} \mathrm{day}^{-1}$ (DelSontro, Beaulieu, \& Downing, 2018).

The relative importance of the turbine flux, compared with the diffusive flux, was higher for $\mathrm{N}_{2} \mathrm{O}$ than for $\mathrm{CH}_{4}$. In Masinga Reservoir, the diffusive $\mathrm{N}_{2} \mathrm{O}$ flux was only $\sim 4$ higher than the $\mathrm{N}_{2} \mathrm{O}$ turbine flux, while the turbine flux was higher than the diffusive flux by a factor of $\sim 2$ and $\sim 5$ in Kamburu and Gitaru reservoirs, respectively (Figure 7).
TABLE 3 Average \pm standard deviation of dissolved methane $\left(\mathrm{CH}_{4}\right)$ and nitrous oxide $\left(\mathrm{N}_{2} \mathrm{O}\right)$ concentrations, diffusive fluxes and turbine fluxes in Masinga, Kamburu and Gitaru reservoirs

\begin{tabular}{|c|c|c|c|}
\hline & \multicolumn{3}{|l|}{ Reservoir } \\
\hline & Masinga & Gitaru & Kamburu \\
\hline Dissolved $\mathrm{CH}_{4}$ concentration ( $\mathrm{nmol} / \mathrm{L}$ ) & $323 \pm 1,015$ & $192 \pm 314$ & $30 \pm 25$ \\
\hline Diffusive $\mathrm{CH}_{4}$ flux $\left(\mu \mathrm{mol} \mathrm{m}{ }^{-2}\right.$ day $\left.^{-1}\right)$ & $216 \pm 666$ & $138 \pm 226$ & $20 \pm 19$ \\
\hline 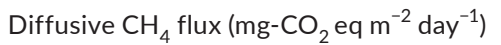 & $118 \pm 362$ & $75 \pm 123$ & $11 \pm 10$ \\
\hline Diffusive integrated $\mathrm{CH}_{4}$ flux (mol/day) & $25,926 \pm 79,907$ & $2,066 \pm 3,397$ & $60 \pm 56$ \\
\hline Turbine integrated $\mathrm{CH}_{4}$ flux (mol/day) & $804 \pm 1,395$ & $234 \pm 199$ & $350 \pm 197$ \\
\hline Dissolved $\mathrm{N}_{2} \mathrm{O}$ concentration ( $\mathrm{nmol} / \mathrm{L}$ ) & $7.5 \pm 2.2$ & $7.4 \pm 1.1$ & $8.6 \pm 1.9$ \\
\hline Diffusive $\mathrm{N}_{2} \mathrm{O}$ flux $\left(\mu \mathrm{mol} \mathrm{m}{ }^{-2}\right.$ day $^{-1}$ ) & $1.0 \pm 1.5$ & $1.1 \pm 0.7$ & $1.6 \pm 1.3$ \\
\hline Diffusive $\mathrm{N}_{2} \mathrm{O}$ flux (mg- $\mathrm{CO}_{2}$ eq $\mathrm{m}^{-2}$ day $^{-1}$ ) & $13 \pm 20$ & $15 \pm 9$ & $22 \pm 18$ \\
\hline Diffusive integrated $\mathrm{N}_{2} \mathrm{O}$ flux (mol/day) & $117 \pm 182$ & $17 \pm 10$ & $5 \pm 4$ \\
\hline Turbine integrated $\mathrm{N}_{2} \mathrm{O}$ flux (mol/day) & $30 \pm 35$ & $28 \pm 28$ & $25 \pm 20$ \\
\hline
\end{tabular}

Notes: Based on data collected from March 2011 to July 2013; concentrations and diffusive fluxes correspond to average intake and inlet data; $\mathrm{CO}_{2}$ equivalent fluxes were computed using global warming potential values at 100 year time frame of 34 and 298 for $\mathrm{CH}_{4}$ and $\mathrm{N}_{2} \mathrm{O}$, respectively (IPCC 2013); diffusive flux spatially integrated with average surface areas reported in Table 1. 

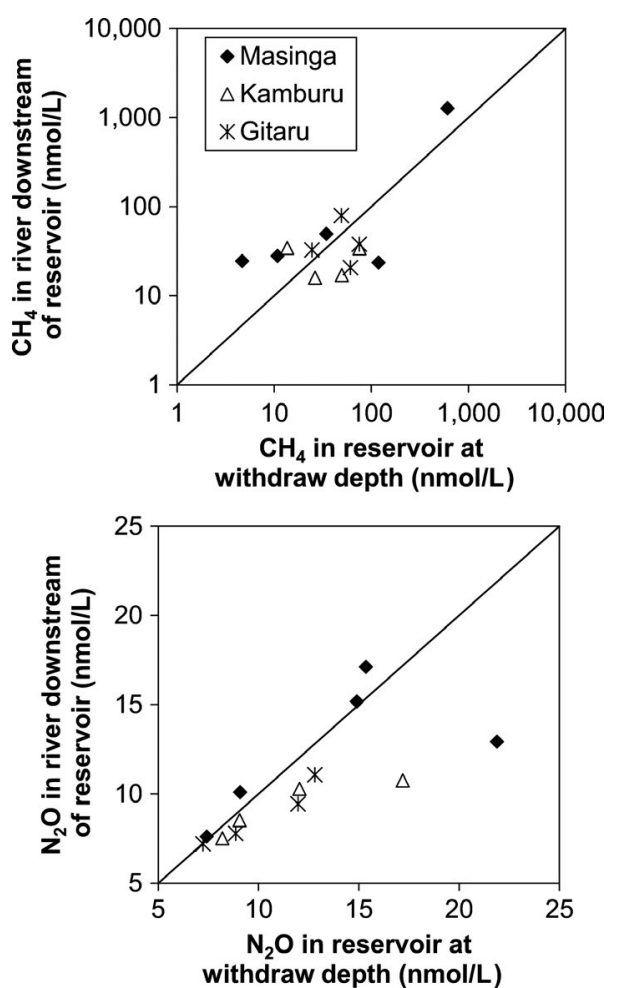

FIGURE 7 Comparison of methane $\left(\mathrm{CH}_{4}\right)$ and nitrous oxide $\left(\mathrm{N}_{2} \mathrm{O}\right)$ concentrations at withdrawal depth within reservoir and corresponding downstream river for Masinga, Kamburu and Gitaru reservoirs from March 2011 to July $2013\left(\mathrm{CH}_{4}\right.$ at withdrawal depth in the reservoir was lower than in downstream river $54 \%$ of the sampling occasions; solid line is 1:1 line)

Turbine fluxes are particularly important emission pathway for reservoirs, particularly when the spilled water is high in GHGs (Guérin \& Abril, 2007) and when the water is withdrawn from the hypolimnion (Kemenes et al., 2007).

\section{4 | CONCLUSIONS}

Very low $\mathrm{CH}_{4}$ and $\mathrm{N}_{2} \mathrm{O}$ fluxes in the Masinga, Kamburu and Gitaru reservoirs were reported, compared with other tropical reservoirs, because of their age (30-40 years) and possibly because of the lower vegetation biomass initially submerged (mainly open deciduous forest and grassland), compared with other tropical reservoirs, such as in South America, which typically contain submerged tropical evergreen forest. The reservoirs with longer water residence times were characterized by higher diffusive $\mathrm{CH}_{4}$ fluxes and slightly lower $\mathrm{N}_{2} \mathrm{O}$ fluxes. The $\mathrm{N}_{2} \mathrm{O}$ diffusive fluxes expressed in $\mathrm{CO}_{2}$ equivalents were nine times lower than the $\mathrm{CH}_{4}$ diffusive fluxes expressed in $\mathrm{CO}_{2}$ equivalents in the reservoir with the longer residence time, but two times higher in the reservoir with the shortest water residence time. The relative contribution of turbine fluxes of $\mathrm{CH}_{4}$ and $\mathrm{N}_{2} \mathrm{O}$, compared with diffusive fluxes, was also highly variable among the three dams, being smaller in Masinga Reservoir and larger in Gitaru Reservoir. Whereas the present study highlights the role of reservoirs in $\mathrm{CH}_{4}$ and $\mathrm{N}_{2} \mathrm{O}$ production, future research should involve a more detailed quantitative assessment of GHG emissions from the Tana River reservoirs, including dedicated field surveys combining $\mathrm{CH}_{4}, \mathrm{~N}_{2} \mathrm{O}$ and direct $\mathrm{pCO}_{2}$ measurements (Abril et al., 2015) at high spatio-temporal resolution, coupled with chamber measurements to determine the water-air exchange fluxes of these GHGs. Future research should also attempt to investigate the emission pathways, especially ebullition, diffusion and turbine fluxes of $\mathrm{CH}_{4}$ (sediment-water and sediment-air during low water level), and their variability in the littoral and pelagic zones.

\section{ACKNOWLEDGEMENTS}

This work was supported by the Flemish Interuniversity CouncilUniversity Cooperation for Development (VLIR-UOS, Belgium) within the framework of the ICP-PhD programme. We are greatly indebted to the Directors of Kenya Marine and Fisheries Research Institute for allowing the use of their facilities; the Kenya Electricity Generating Company for granting access to the reservoirs and providing discharge data, and the Water Resources Management Authority for providing discharge data for the R1 sampling site. The efforts by KMFRI staff (Vero Wanjeri, Sturcky Okumu, Oliver Ocholla, Samuel Njoroge, Peter Chiteri, and Jeremiah Mokua), who were tirelessly involved in field sampling, are also gratefully appreciated. This work contributes to the European Research Council (ERC) starting grant project AFRIVAL (African river basins: Catchment scale carbon fluxes and transformations, 240002). The GC was acquired with funds from the Fonds National de la Recherche Scientifique (FNRS) (contract no. 2.4.598.07). AVB is a senior research associate at the FNRS. We also thank two anonymous reviewers for their constructive comments on an earlier draft of this manuscript.

\section{ORCID}

Eric O. Okuku (iD https://orcid.org/0000-0002-2459-0215

\section{REFERENCES}

Abril, G., Bouillon, S., Darchambeau, F., Teodoru, C., Marwick, T. R., Tamooh, F., ... Borges, A. V. (2015). Technical Note: Large overestimation of $\mathrm{pCO}_{2}$ calculated from $\mathrm{pH}$ and alkalinity in acidic, organic-rich freshwaters. Biogeosciences, 12, 67-78.

Abril, G., Guérin, F., Richard, S., Delmas, R., Galy-Lacaux, C., Gosse, P., ... Matvienko, B. (2005G). Carbon dioxide and methane emissions and the carbon budget of a 10-year old tropical reservoir (Petit Saut, French Guiana). Global Biogeochemical. Cycles, 19, GB4007. https:// doi.org/10.1029/2005GB002457

APHA. (1998). Standard method for the examination of water and wastewater, 20th ed. Washington, D.C.: APHA.

Barros, N., Cole, J. J., Tranvik, L. J., Prairie, Y. T., Bastviken, D. T., \& Huszar, V. L. M. (2011). Carbon emission from hydroelectric reservoirs linked to reservoir age and latitude. Nature Geoscience, 4, 593-596.

Bastviken, D., Tranvik, L., Downing, J. A., Crill, P. M., \& Enrich-Prast, A. (2011). Freshwater methane emissions offset the continental carbon sink. Science, 331, 50. 
Beaulieu, J. J., Smolenski, R. L., Nietch, C. T., Townsend-Small, A., Elovitz, M. S., \& Schubauer-Berigan, J. P. (2014). Denitrification alternates between a source and sink of nitrous oxide in the hypolimnion of a thermally stratified reservoir. Limnology and Oceanography, 59, 495-506.

Borges, A. V., Darchambeau, F., Teodoru, C. R., Marwick, T. R., Tamooh, F., Geeraert, N., ... Bouillon, S. (2015). Globally significant greenhouse-gas emissions from African inland waters. Nature Geoscience, 8, 637-642.

Brown, T., \& Schneider, H. (1998). The sustainable management of tropical catchments, Edited by: Harper, D. and Brown, T. Chichester, UK: John Wiley and Sons.

Brown, T., Schneider, H., \& Harper, D. (1996). Multi-scale estimates of erosion and sediment yields in the upper Tana basin, Kenya. In D. E. Walling, \& B. W. Webb (Eds.), Erosion and Sediment yield: Globaland Regional perspectives. Proceedings of the Exeter Symposium, July 1996 (pp. 49-54). Wallingford, UK: IAHS Press.

Cole, J. J., \& Caraco, N. F. (1998). Atmospheric exchange of carbon dioxide in a low-wind oligotrophic lake measured by the addition of SF6. Limnology and Oceanography, 43, 647-656.

Deemer, B. R., Harrison, J. A., Li, S., Beaulieu, J. J., Delsontro, T., Barros, N., ... Vonk, J. A. (2016). Greenhouse gas emissions from reservoir water surfaces: A new global synthesis. BioScience Advance Access, 66, 949-964.

DelSontro, T., Beaulieu, J. J., \& Downing, J. A. (2018). Greenhouse gas emissions from lakes and impoundments: Upscaling in the face of global change. Limnology and Oceanography Letters, 3, 64-75.

Demarty, M., \& Bastien, J. (2011). GHG emissions from hydroelectric reservoirs in tropical and equatorial regions: Review of 20 years of $\mathrm{CH}_{4}$ emission measurements. Energy Policy, 39, 4197-4206.

Descloux, S., Chanudet, V., Serça, D., \& Guérin, F. (2017). Methane and nitrous oxide annual emissions from an old eutrophic temperate reservoir. Science of the Total Environment, 598, 959-972.

Deshmukh, C. (2013). Greenhouse gas emissions (CH4, CO2 and N2O) from a newly flooded hydroelectric reservoir in subtropical South Asia: The case of Nam Theun 2 Reservoir, Lao PDR. Ocean, Atmosphere. Universite Paul Sabatier- Toulouse III.

Fearnside, P. M. (1995). Hydroelectric dams in the Brazilian Amazon as sources of 'greenhouse' gases. Environmental Conservation, 22, 7-19.

Fearnside, P. M. (2002). Greenhouse gas emissions from a hydroelectric reservoir (Brazil's Tucuruí dam) and the energy policy implications. Water, Air and Soil Pollution, 133, 69-96.

Galy-Lacaux, C., Delmas, R., Kouadio, J., Richard, S., \& Gosse, P. (1999). Long-term greenhouse gas emissions from hydroelectric reservoirs in tropical forest regions. Global Biogeochemical Cycles, 13, 503-517.

Grinham, A., Dunbabin, M., Gale, D., \& Udy, J. (2011). Quantification of ebullitive and diffusive methane release to atmosphere from a water storage. Atmospheric Environment, 45, 7166-7173.

Guerin, F., \& Abril, G. (2007). Significance of pelagic aerobic methane oxidation in the methane and carbon budget of a tropical reservoir. Journal of Geophysical Research, 112, 1-14.

Guérin, F., Abril, G., Tremblay, A., \& Delmas, R. (2008). Nitrous oxide emissions from tropical hydroelectric reservoirs. Geophysical Research Letters, 35, L06404.

Hoffert, M. I., Caldeira, K., Jain, A. K., Haites, E. F., Harvey, L. D. D., Potter, S. D., ... Wuebbles, D. J. (1998). Energy implications of future stabilization of atmospheric $\mathrm{CO}_{2}$ content. Nature, 395, 881-884.

IPCC (2006). 2006 National Greenhouse Gas Inventory Guidelines [Eggelston, S., Buendia, L., MiwaK., Ngara, T., \& Tanabe, K. (Eds.)]. Kanagawa, Japan: Institute of Global Environmental Strategies (IGES). pp. 20.

IPCC. (2013). The Physical Science Basis. In T. F. Stocker, D. Qin, G.-K. Plattner, M. Tignor, S. K. Allen, J. Boschung, A. Nauels, Y. Xia, V. Bex, \& P. M. Midgley (Eds.), Contribution of Working Group 1 to the Fifth Assessment Report of the Intergovernmental Panel on Climate Change (pp. 1535). Cambridge, UK and New York, NY: Cambridge University Press.

Kemenes, A., Forsberg, B. R., \& Melack, J. M. (2007). Methane release below a tropical hydroelectric dam. Geophysical Research Letters, 34, L12809.
Kemenes, A., Forsberg, B. R., \& Melack, J. M. (2011). $\mathrm{CO}_{2}$ emissions from a tropical hydroelectric reservoir (Balbina, Brazil). Journal of Geophysical Research, 116,1-11.

Liu, X. L., Liu, C. Q., Li, S. L., Wang, F. S., Wang, B. L., \& Wang, Z. L. (2011). Spatiotemporal variations of nitrous oxide $\left(\mathrm{N}_{2} \mathrm{O}\right)$ emissions from two reservoirs in SW China. Atmospheric Environment, 45, 5458-5468.

Maavara, T., Lauerwald, R., Regnier, P., \& Van Cappellen, P. (2016). Global perturbation of organic carbon cycling by river damming. Nature Communications, 8, 15347.

Maeck, A., DelSontro, T., McGinnis, D. F., Fischer, H., Flury, S., Schmidt, M., ... Lorke, A. (2013). Sediment trapping by dams creates methane emission hot spots. Environmental Science and Technology, 47, 8130-8137.

Parsons, T., Maita, Y., \& Lally, C. (1984). A manual of chemical and biological methods of seawater analysis (p. 173). Oxford, UK: Pergamon Press.

Raymond, P. A., Hartmann, J., Lauerwald, R., Sobek, S., McDonald, C., Hoover, M., ... Guth, P. (2013). Global carbon dioxide emissions from inland waters. Nature, 503, 355-359.

Snoussi, M., Kitheka, J., Shaghude, Y., Kane, A., Arthurton, R., Le Tissier, M., \& Virji, H. (2007). Downstream and coastal impacts of damming and water abstraction in Africa. Environmental Management, 39, 587600. https://doi.org/10.1007/s00267-004-0369-2

St. Louis, V. L., Kelly, C. A., Duchemin, E., Rudd, J. W. M., \& Rosenberg, D. M. (2000). Reservoir surfaces as sources of greenhouse gases to the atmosphere: A global estimate. BioScience, 50, 766-775.

Sturm, K., Yuan, Z., Gibbes, B., Werner, U., \& Grinham, A. (2014). Methane and nitrous oxide sources and emissions in a subtropical freshwater reservoir, South East Queensland, Australia. Biogeosciences, 11, 5245-5258.

Teodoru, C. R., Bastien, J., Boonneville, M. C., De Giorgio, P. A., Demarty, M., Garneau, M., ... Tremblay, A. (2012). The net carbon footprint of a newly created boreal hydroelectric reservoir. Global Biogeochemical Cycles, 26, GB2016.

Tremblay, A., Varfalvy, L., Roehm, C., \& Garneau, M. (2005). Greenhouse gas emissions- fluxes and processes. Hydroelectric reservoirs and natural environments, 1st ed. Berlin, Germany: Springer.

Tundisi, J. G., Matsumura-Tundisi, T., \& Calijuri, M. C. (1993). Limnology and management of reservoirs in Brazil. In M. Straškraba, J. G. Tundisi, \& A. Duncan (Eds.), Comparative reservoir limnology and water quality management. Developments in Hydrobiology (pp. 25-55). Springer Netherlands.

Tundisi, J. G., \& Tundisi, T. M. (2012). Limnology. Leiden, The Netherlands: CRC Press/Balkema.

Victor, D. G. (1998). Strategies for cutting carbon. Nature, 395, 837-838.

Yang, L., Lu, F., Zhou, X., Wang, X., Duan, X., \& Sun, B. (2014). Progress in the studies on the greenhouse gas emissions from reservoirs. Acta Ecologica Sinica, 34, 204-212.

Zhu, D., Chen, H., Yuan, X., Wu, N., Gao, Y., Wu, Y., ... Wu, J. (2013). Nitrous oxide emissions from the surface of the Three Gorges Reservoir. Ecological Engineering, 60, 150-154.

\section{SUPPORTING INFORMATION}

Additional supporting information may be found online in the Supporting Information section at the end of the article.

How to cite this article: Okuku EO, Bouillon S, Tole M, Borges AV. Diffusive emissions of methane and nitrous oxide from a cascade of tropical hydropower reservoirs in Kenya. Lakes \& Reserv. 2019;00:1-9. https://doi.org/10.1111/ Ire.12264 